\title{
Nastroje prawicowo-ekstremistyczne społeczeństwa niemieckiego
}

\begin{abstract}
Streszczenie: Głównym tematem artykułu jest analiza prawicowo-ekstremistycznych nastrojów w społeczeństwie niemieckim, których rzecznikiem stają się coraz częściej przedstawiciele klasy średniej. Nieudany projekt wielokulturowości niemieckiej, długotrwały kryzys gospodarczy w Europie, zjawisko terroryzmu islamskiego i fala uchodźców stworzyły atmosferę ksenofobizmu i rasizmu. W efekcie tworzone są partie oraz nieformalne ugrupowania, które oczekują od państwa zmian w polityce azylowej i artykułują potrzebę utrwalania tożsamości narodowej.

Tworzące się ad hoc ruchy społeczne odnoszą się krytycznie do niemieckiego systemu politycznego gromadząc określoną część elektoratu. Jeden z ruchów obywatelskich pod nazwą Pegida demonstruje nie tylko przeciwko radykałom muzułmańskim, a islamowi w ogóle. Organizatorzy i zwolennicy Pegidy dystansują się publicznie od ekstremistów prawicowych, ale wykorzystują lęki przed islamskim terrorem i szerzą nastroje niechęci wobec uchodźców i obcych. Pytanie badawcze dotyczy perspektyw utrwalania demokratycznych standardów w pozjednoczeniowym społeczeństwie niemieckim przez klasę średnią, która może stać się najważniejszym elementem wpływającym na opinię publiczną. Renesans ideologii faszystowskiej wymusił konieczność wykreowania nowego modelu komunikowania społecznego pomiędzy klasami. Percepcja tej ideologii jest przedmiotem badawczym sfery aksjologicznej.
\end{abstract}

Słowa kluczowe: multikulturowość, antysemityzm, AfD, prawicowy ekstremizm

\section{Wstęp}

$\mathbf{N}$ owe tysiąclecie jest dla Republiki Federalnej Niemiec okresem wzmożonej aktywności ruchów społecznych i obywatelskich. Stopniowy „demontaż” państwa socjalnego, kryzys światowy i coraz większe koszty partycypacji w strukturach unijnych wywołują obawy o stabilność, dobrobyt i bezpieczeństwo kraju. Nieudany projekt multikulturowości dodatkowo wzmocnił ,zalew” uciekinierów z Syrii, Iraku, co wywołuje skrywane w niemieckim społeczeństwie pokłady rasizmu i ksenofobii. Obywatele Niemiec tworzą nieformalne organizacje i nowe partie, które sprzeciwiają się niekontrolowanemu napływowi imigrantów i postulują zmianę polityki państwa w tym zakresie. Artykuł prezentuje genezę społecznego buntu, dokonuje jego analizy społecznej i przedstawia nowe modele komunikowania społecznego. Pytanie badawcze dotyczy perspektyw utrwalania demokratycznych standardów w pozjednoczeniowym społeczeństwie niemieckim przez klasę średnią, która może stać się „nośnikiem” prawicowo-ekstremistycznego mainstreamu.

\section{Ideologia prawicowego ekstremizmu}

Pojęcie ekstremizmu, rozumiane jako kompleks wielu poglądów i idei, różniących się od wartości ogólnie przyjętych, dotyczy skrajnych poglądów, alternatywnych ide- 
ologii, które plasują się na najdalej wysuniętych krańcach osi lewica-prawica, biorąc za punkt odniesienia umiarkowaną i pro-systemową politykę środka. Ekstremizm cechuje relatywizm, gdyż oceniany jest przez pryzmat powszechnie przyjętych norm i stąd ustanowienie spójnej typologii ekstremizmu stanowi problem. Jednoznaczne określenie ideologiczne ruchów społecznych czy ugrupowań politycznych zależne jest od uznawanych autorytetów i liderów tych grup, z których wypowiedziami identyfikują się dane społeczności (Backes, Jesse, 1998, s. 15). Obok kryterium przestrzennego w warstwie ideologicznej organizacji prawicowo-ekstremistycznych promowana jest naturalna wspólnota, której nośnikiem są hasła faszystowskie, a na poziomie legitymizacyjnej podważany jest istniejący porządek prawny (Pomarański, 2011, s. 133-135). Według turyńskiego filozofa Norberta Bobbio skrajna prawica neguje zasadę wolności i równości człowieka, co wyrażane jest w dyskryminacji rasowej, etnicznej, religijnej (Bobbio, 1996).

Nastroje prawicowo-ekstremistyczne społeczeństwa niemieckiego postrzegane są $\mathrm{w}$ artykulacji haseł nacjonalistycznych, gloryfikacji rodzimej kultury i negacji dotychczasowej polityki partii sprawujących władzę. Wraz z polaryzacją kulturową odrzucane są obowiązujące konwenanse społeczne i postulowane zmiany w funkcjonowaniu systemu politycznego w ramach liberalno-demokratycznego statusu państwa prawa. Na bazie kanonu odmiennych doświadczeń okresu zjednoczeniowego faworyzowane są ,nowe” partie o zabarwieniu skrajnie prawicowym, które różnią się od „starych”, odwołujących się głównie do ideologii narodowosocjalistycznej. Ontologiczne kryterium wyróżniające ekstremizm jednostkowy i grupowy (Tokarczyk, 2003) przekształca ekstremizm prawicowy w różne warianty, w zależności od usytuowania klasowego, osobistych doświadczeń i poziomu alienacji.

\section{Problemy $\mathrm{z}$ imigrantami}

Nastawienie Niemców do ideologii prawicowego ekstremizmu jest negatywne. W porównaniu z wieloma państwami europejskimi, gdzie skrajna prawica cieszy się największą popularnością od czasów II wojny światowej (np. francuski Front Narodowy, węgierski Jobbik, włoski Ruch Społeczny - Trójkolorowy Płomień) w Republice Federalnej Niemiec pozostaje ona nadal fenomenem regionalnym. Prawicowi ekstremiści z Narodowo-Demokratycznej Partii Niemiec (NPD) nigdy od czasów powstania RFN nie zasiadali w Bundestagu. W okresie ostatnich pięciu lat 2010-2015 w żadnym Landtagu nie uzyskali też mandatu. Długoletnie działania edukacyjne prowadzone przez Federalny Urząd Ochrony Konstytucji i Ministerstwo Spraw Wewnętrznych zmarginalizowały populistyczne hasła nacjonalistyczne w świadomości społecznej. Nieprzychylna atmosfera, szczególnie wobec NPD pogłębiła się, gdy w 2011 r. wyszły na jaw kulisy zbrodni terrorystycznej grupy Narodowosocjalistyczne Podziemie (niem. Nationalsozialistischer Untergrund - NSU) powiązanej z brunatnymi z Turyngii (Janicka, 2015, s. 88-95). Na tle tych trwających dekadę przestępstw pojawiła się nieporadność, nonszalancja i celowa bezradność tajnych służb wewnętrznych państwa w wykrywaniu sprawców. Federalny Urząd Ochrony Konstytucji powołany do ochrony państwa i obywateli przed organizacjami i partiami, których zwolennicy zmierzają do naruszenia albo obalenia porządku konstytucyjnego RFN nie wykazał dostatecznej determinacji w wyjaśnieniu trwającej wiele lat fali morderstw. Sła- 
bość służb jest często równoznaczna ze słabością państwa. Podejrzenie o współdziałanie z przestępcami dodatkowo kładzie się cieniem na wizerunku instytucji zaufania publicznego. Zjawisko to ma swoje umocowanie w nastrojach społecznych, gdzie akceptowane są agresywne i nieprzejednane postawy wobec obywateli innych narodowości żyjących w Niemczech (Janicka, 2013, s. 219-232). Ten „kompleks NSU” kładzie się cieniem na całe społeczeństwo i stało się podstawą kontynuowania dalszych gruntownych badań nad rozmiarem i siłą tych nastrojów w poszczególnych grupach obywateli. Trwanie ładu demokratycznego zależy w dużej mierze od opinii formułowanych przez jednostki w danym środowisku jak i całych grup społecznych, zwolenników budowania porozumień politycznych, w aksjologicznym ujęciu zasad demokracji.

O kulturze politycznej społeczeństwa świadczą wybrane metody rozwiązywania konfliktów, tworzenie norm i właściwych jakości zachowania politycznego obywateli i rządzących elit. Społeczeństwo samo bez nadzoru i kontroli państwa, wykorzystując zdobycze demokratyczne jest $\mathrm{w}$ stanie przeciwstawić się niekontrolowanemu rozwojowi ideologii antydemokratycznych, zagrażających jego istnieniu. W nastrojach wielkich grup społecznych decydująca rolę odgrywają takie czynniki jak: poczucie wolności, ocena warunków bytu materialnego, stosunek do pracy. Przy stykaniu się rozmaitych poglądów uwydatniają się trwałe cechy psychologii grupy, a także potrzeby, interesy, sympatie, antypatie. „Nastroje społeczne - jak słusznie zauważył Mojsiewicz - w sposób najbardziej bezpośredni odbijają wszystkie zmiany zachodzące w systemie stosunków społecznych i najczęściej rozlewają się w szeroką, mniej lub bardziej burzliwą falę w społeczeństwie" (Mojsiewicz, 1999, s. 33).

Republika Federalna Niemiec zajmuje obecnie drugie miejsce po USA na świecie pod względem „napływu” imigrantów. W 2013 roku przybyło ich prawie 460 tys., ponad połowa przybywa ze wschodnich krajów UE, najwięcej 17,1\% z Polski, 12,1\% z Rumunii, 5,3\% z Bułgarii. W Niemczech mieszka 16,3 mln osób o korzeniach imigracyjnych (urodzili się za granicą lub są potomkami imigrantów). Jednak największy gniew skupia się na liczącej $4 \mathrm{mln}$ osób grupie muzułmanów. Niemcy odczuwają coraz silniejsze zagrożenie dla własnej tożsamości narodowej, stąd liczne ataki na meczety. Gdy w latach 2001-2013 odnotowano średnio 22 podpalenia i inne ataki, to w latach 2012-2014 - zarejestrowano ich 78 (Jendroszczyk, 2014, s. A9).

Tempo rozwoju wspólnoty muzułmańskiej w Europie, emigracja, a także brak pomysłu na skuteczną inkulturację wyznawców islamu marginalizuje tę grupę społeczną w państwach tzw. „cywilizacji Zachodu”. Oświeceniowe prawa człowieka i obywatela, które są istotą Zachodu wywodzą się z chrześcijańskiego rozdzielenia władzy boskiej i cesarskiej oraz wartości rewolucji francuskiej. Pomimo faszystowsko-totalitarnej pokusie, jakiej uległy Niemcy w XX wieku stanowią nadal przeciwwagę w tendencjach republikańsko-demokratycznych wobec islamu. Pierwsze pokolenie emigrantów jest najbardziej łagodne, drugie próbuje się asymilować, ale trzecie wraca do religijności i wybiera najbardziej radykalne jej elementy. Przykładem zatracenia się w radykalizmie stał się 22-letni Arid U. urodzony w Kosowie, który 2 marca 2011 roku zastrzelił dwóch żołnierzy USA, a dwóch ranił na lotnisku we Frankfurcie (Bartsch, Stark, 2011, s. 44-45). Ten pierwszy udany atak islamisty na niemieckiej ziemi jest nie tylko najgorszą forma , homegrown terrorist”, ale podważa również niemiecki model edukacyjny. Izolacja środowiskowa w połączeniu z wirtualnym światem powoduje rozdarcie kulturowe, którego efekty trudne są do przewidzenia. 
Fala nienawiści i wzmożonej agresji wobec obcokrajowców ma miejsce w landach wschodnich, gdzie ilość imigrantów jest niższa niż w zachodniej części kraju. Wyjątkowo spektakularne ataki odbywają się w małych spokojnych miastach Saksonii. W Budziszynie zaatakowano kolumbijskiego ucznia, w Hoyerswerde wybijano szyby w biurach poselskich, w Geithain eksplodowała pizzeria należąca do Pakistańczyka. W regionach pomiędzy Lipskiem i Chemnitz umocniły się neofaszystowskie struktury Freies Netz, który jest nieformalnym związkiem bojówek Kameradschaften. Sieją terror w okolicy, prześladują swoich przeciwników, grożą atakami na ich domy, samochody i publikują dane osobowe w Internecie (Popp, 2012, s. 30-32).

Drezdeńscy populiści protestują przeciwko islamizacji Niemiec z hasłami „Putin pomóż”. Saksonia Anhalt, gdzie muzułmanów jest niewielu zmaga się z falą masowych protestów przeciwko planowanemu otwarciu domu dla uchodźców. Szczególnie aktywna jest ekstremistyczna NPD, która z inicjatywy lancowego przywódcy partii Steffen Thiela organizowała cotygodniowe demonstracje pod nazwą Lichterspaziergänge, skupiające ponad 100 uczestników. Coraz częściej przemarsze kończyły się pod oknami prywatnego domu burmistrza miasta Tröglitz Markusa Niertha (CDU). W marcu 2015 r. w obawie o życie swoje i swojej rodziny ustapił on ze stanowiska burmistrza, a miesiąc później ktoś podłożył ogień w przyszłej siedzibie dla 50 uchodźców w Tröglitz (Bürgermeister).

Landy wschodnie, prosperowały przed zjednoczeniem z wydobycia węgla, obecnie borykają się z dużym bezrobociem i wyludnieniem. Młodzi ludzie wyjechali na zachód w poszukiwaniu pracy, partie wycofały się, a ich miejsce zajęli neofaszyści - w radzie miasta Geithain zasiada od roku 2009 Manuel Tripp, reprezentant NPD. Mieszkańcy tych regionów czują się opuszczeni przez władze regionalne, urzędnicy nie radzą sobie z dokumentowaniem zagrożeń, a premier Saksonii Stanislaw Tillich (CDU) zaprzecza jakoby radykalizm prawicowy był znaczącym problemem dla tego landu. Wyjątkowa obstrukcja rządu nie dziwi, skoro „trio NSU” przez 10 lat ukrywało się na jego terytorium.

Nowym problemem, z jakim musi zmierzyć się Republika Federalna Niemiec jest nie tylko brak ośrodków dla uciekinierów, których liczba podwoiła się z zakładanych 1,5 tys. w roku 2014, ale niewypracowana polityka postępowania z nieletnimi imigrantami z Afryki, którzy coraz częściej wywołują awantury i są niezdyscyplinowani. Minister pracy i polityki społecznej w bawarskim rządzie Horsta Seehofera Emilia Müller przyznała na łamach „Süddeutsche Zeitung”, że wzrosło zapotrzebowanie na pracowników socjalnych, a obecni nie radzą sobie z postępującą agresją młodych azylantów i nie chcą tej pracy wykonywać. Młodzież w wieku 15-17 lat klasyfikowana przez urzędników Jugendhilfe skrótem umF (unbegleiteter minderjähriger Flüchtling - niepełnoletni uchodźca bez towarzystwa) ma możliwość bezpłatnej nauki niemieckiego i zawodu, korzysta z opieki zdrowotnej i pomocy społecznej, ale zmaga się z chorobami psychicznymi i stresem w nieznanym im kraju (Osiński, 2015, s. 30-32).

\section{Protesty spoleczne}

Na podłożu działań człowieka, wywierających wpływ na współczesne państwo, są ruchy społeczne. Jedną z cech każdego ruchu społecznego jest masowość. Obywatele przekonani o swojej racji świadomie i celowo dążą do realizacji celu, kierując się 
wspólnymi wartościami i wspólną ideologią (Szczepański, 1970). Osiagnnięcie celu warunkuje właściwie skonstruowana strategia, taktyka i adekwatny dobór środków masowej komunikacji. Elementem spajającym uczestników manifestacji i wieców jest charyzmatyczny lider, oprawa propagandowa oraz ideologia, która mobilizuje do aktywności. Brak rozwiązań kwestii społecznych, który „zrodzil” dany ruch, przekształca je z wydarzeń jednostkowych w długotrwały proces (Przybylski, 1975), którego skutki są nie do przewidzenia.

Federalne i krajowe urzędy ochrony konstytucji pomimo upływu lat i zmian geopolitycznych nadal zajmują się ,tropieniem” ruchów antysystemowych, których działalność propagandowa i polityka informacyjna wpływa na radykalizację postaw społecznych. W drugiej dekadzie nowego tysiąclecia zagrożeniem dla RFN są radykalizujące się postawy obywateli. Ponownie odżywają nastroje o charakterze nacjonalistycznym, ksenofobicznym i anty-imigracyjnym. Powstają prawicowo-populistyczne inicjatywy takie jak: Ruch Obywatelski „Za” (Pro Bewegung), umiarkowanie krytyczne wobec islamu ugrupowanie Wściekli Obywatele (Bürger in Wut) i Ruch protestu przeciwko Islamizacji Niemiec (niem. Patriotische Europäer gegen die Islamisierung des Abendlandes - PEGIDA). Antyeuropejską ofertę programową przedstawiła utworzona tuż przed wyborami do Parlamentu Federalnego w 2013 r. partia Alternatywa dla Niemiec (Alternative für Deutschland) i niewiele brakowało by jej przedstawiciele zasiedli w lawach Bundestagu.

Przedstawiciele klasy średniej reagują w sposób bardziej przemyślany i organizują ruchy obywatelskie, przekształcane następnie w partie jak miało to miejsce w przypadku powołanego do życia w 1996 roku Ruchu Obywatelskiego Za Kolonią (Bürgerbewegung pro Köln), z którego inicjatywy powołano w 2005 roku partię Ruch Obywatelski Zza Niemcami (Bürgerbewegung pro Deutschland) z siedzibą w Berlinie, a następnie Partię Ruch Obywatelski Za Nadrenią Północną-Westfalią (Bürgerbewegung pro NordhreinWestfalen - pro NRW) w 2007 roku (Häusler, 2009, s. 130). W latach 2008-2011 partia Za Nadrenią Północną Westfalią zorganizował dwa Kongresy Przeciwko Islamizacji, jeden Kongres przeciwko Minaretom oraz zainicjowała Marsz za Wolnością (MoroskaBonkiewicz, 2013, s. 129).

W roku 2014 ruchy neonazistowskie zyskały dodatkowe wzmocnienie społeczne w postaci oddolnego ruchu obywatelskiego Patriotyczni Europejczycy przeciwko Islamizacji Zachodu (niem. Patriotische Europäer gegen die Islamisierung des Abendlandes). Pod sztandarami PEGIDY w demonstracjach w Dreźnie, Bonn, Kassel, Würzburgu gromadzili się przeciwnicy coraz większej obecności islamu w Europie, co stanowi zagrożenie dla bytu i wartości kultury chrześcijańskiej. W opublikowanym 19-punktowym programie domagają się między innymi wprowadzenia do ustawy zasadniczej obowiązku integracji nowych przybyszy z niemieckim społeczeństwem i oczekują stworzenia transparentnego katalogu zasad postępowania z imigrantami w sposób nieuwłaczający ich godności.

Pierwsze analizy socjologiczne Pegidy wykazały, że typowy demonstrant jest mężczyzną, w wieku średnim o ponadprzeciętnych zarobkach, bezwyznaniowy. Nie jest apolityczny, ma autorytarny stosunek do polityki, która powinna szybko rozwiązywać denerwujące go problemy. Skoro zmian nie ma, gdyż demokracja w swojej naturze jest powolna, to aktorzy polityki - leniwi i nieudolni politycy zasługują na 
pogardę. 3/4 zwolenników Pegidy nie czuje się reprezentowana przez swoje partie i polityków.

Obywatele Niemiec przyznają, że media publiczne tabuizują i pomijają problematykę skutków polityki imigracyjnej. Swoje niezadowolenie artykułują nie tylko na ulicach miast, ale głównie w mediach społecznościowych, które stanowią przeciwwagę dla mediów mainstreamowych. Teorię spiskową o przekupnych dziennikarzach podtrzymuje w internecie były dziennikarz „Frankfurter Allgemeine Zeitung” Udo Ulfkotte. Jego książka Gekaufte Journalisten stała się bestsellerem już w dniu wydania. Młody urzędnik z Monachium prowadzi od 2012 jeden z większych portali internetowych sceny narodowo-konserwatywnej pod nazwą Blu-News (skrót Blu pochodzi od słów bürgerlich, liberal, unabhänging). Każda strona podlinkowuje następne, które tworzą paralelny świat, będący „cudownym lekiem na uczucie wyobcowania”. Prawie 300000 odsłon potwierdza wyjątkową aktywność obywateli w tej kwestii. Członkowie i zwolennicy AfD utworzyli grupę facebookową o nazwie „Patriotische Platform”, a założyciele strony pod nazwą „Nürnberg 2.0 Deutschland” grożą prominentnym politykom RFN m.in. byłemu prezydentowi Christianowi Wulffowi procesem sądowym na wzór procesów norymberskich za „systematyczną islamizację Niemiec”. Wrogi islamowi blog „PoliticallyIncorrect" odnotowuje dziennie 70000 odwiedzin. Saksoński trzydziestoletni intelektualista, medioznawca publikuje na portalu online od 10 lat prawicowo-konserwatywny magazyn „Blaue Narzisse” dla studentów i uczniów. Na fali panującej nienawiści powstają też struktury bojowe jak Niemiecki Ruch Oporu (Deutsche Widerstandsbewegung - DWB), który stoi za czterema próbami podpalenia urzędów federalnych; w tym siedziby CDU, berlińskiego Reichstagu i jednego z budynków Bundestagu - Paul-Löbe Haus. Ta grupa społeczna neguje dotychczasową politykę imigracyjną państwa i twierdzi, że „multikulturowość, multietniczność, mutlireligijność i multihistoryczność targa krajem i go bałkanizuje" (Baumgärtner, Diehl, 2014, s. 26).

Demonstranci nie stanowią homogenicznej grupy. Są w niej neonaziści, prawicowi ekstremiści, zwykli chuligani i sfrustrowani, niepozorni obywatele. Przez okres 10 lat Wilhelm Heitmeyer wraz z grupa badaczy z Uniwersytetu w Bielefeldzie badali nastawienie obywateli Niemiec do osób niedostosowanych lub wyalienowanych społecznie. Badania wykazały, że od 10 do $20 \%$ społeczeństwa ma stałe nastawienie wrogie wobec mniejszości tj. obcokrajowców, Żydów, bezrobotnych, homoseksualistów i wszystkich „aspołecznych”, zdefiniowanych jako „grupowa mizantropia” (,gruppenbezogene Menschenfeidlichkeit" - GMF). Heitmeyer badając klimat społeczny określił go mianem ideologii nierówności (Ideologie Ungleichwertigkeit) ${ }^{1}$. W okresie słabej koniunktury

${ }^{1}$ Efektem długoletnich badań empirycznych była publikacja pod tytułem Niemieckie stany, która od 10 lat ma coroczne edycje. Realizację projektu rozpoczęto w roku 2002 dzięki wsparciu finansowemu dwóch fundacji Volkswagena i Freudenberga. Przez lata wywoływał on duży społeczny i naukowy wydźwięk, inicjując podobne badania za granicą i studia porównawcze o charakterze międzynarodowym. Indagowano w sumie 23000 osób i opublikowano około 150 prac naukowych. Koncepcja „grupowej mizantropii” obejmowała na początku 6 elementów: rasizm, heterofobia, antysemityzm, protekcjonizm, seksizm, ksenofobia. Przyjęto tezę o istnieniu syndromu, w centrum którego znajduje się ideologia nierównych wartości. Operacjonalizację poprawiono i poszerzono o kilka elementów syndromu. Pierwotną heterfobię zróżnicowano na homoseksualistów, osoby niepełnosprawne, bezdomne. Wobec wydarzeń politycznych na świecie dodano antysemityzm powiązany z Izraelem. Po kilku latach badań do syndromu włączono trwale bezrobotnych, następnie ubiegających się o azyl, oraz Sinti 
gospodarczej przy braku socjalnego wsparcia postawy wrogie nasilają się i przybierają agresywną formę (Heitmeyer, 2012). To zjawisko w połączeniu z prawicowym ekstremizmem jest szczególnie niebezpieczne dla demokracji. Dotyczy ono wszystkich grup społecznych i występuje zarówno w landach wschodnich jak i zachodnich, wśród młodych jak i starszych, pośród kobiet jak i mężczyzn, oraz wśród osób plasujących się w socjoekonomicznym i politycznym środku. Czy obecne nastawienie społeczne wobec „obcych" nie jest pokłosiem książki Thilo Sarrazina z 2010 roku pt. Niemcy same się zniszcza (Deutschland schafft sich $a b$ ) pozostaje pytaniem otwartym, ale warto zwrócić uwagę, że to pośród przedstawicieli klasy średniej odniosła ona największy sukces czytelniczy. Liczne debaty, wywołane publikacją książki ujawniły głębokie podziały społeczno-kulturowe, rosnącą retorykę anty-imigracyjną i oficjalne przyznanie kanclerz Merkel, że wielonarodowe społeczeństwo niemieckie poniosło klęskę.

Wolfgang Thierse, długoletni prezydent Parlamentu Federalnego jest zdania, że dotychczasowa polityka unikania konfrontacji z krytycznie nastawionymi obywatelami prowadzi donikąd. W zamian proponuje pięciopunktowy plan terapeutyczny, w którym na pierwszym miejscu jest konstruktywny dialog, krytyczne przeciwstawienie się argumentom drugiej strony i spotkania z krytycznie nastawionymi obywatelami, wykluczając przedstawicieli prawicowej ekstremy. Drugim założeniem jest przypomnienie krytykom o odpowiedzialności za wspólnotę demokratyczną, która rządzi się odrębnymi prawami niż systemy autorytarne. Jego zdaniem należy też uświadomić populistycznym demagogom, że niebezpieczeństwo islamizacji kraju nie istnieje, gdyż niemieckie państwo prawa przeciwdziała ruchom salafitów i występuje przeciwko wszystkim sprawcom przestępstw, bez względu na reprezentowaną przez nich ideologię. Czwartym lekiem pozostaje język dyskusji, oparty na nieomijaniu tematów trudnych, które nękają wiele grup społecznych. Lęki i uprzedzenia nie są przezwyciężane w drodze obelg, a w duchu wzajemnego zrozumienia i dyskusji na argumenty. Thierse w piatym punkcie swojego planu oczekuje wreszcie szerokiej dyskusji nad specyfiką funkcjonowania państwa imigrantów, jakim stała się i pozostanie Republika Federalna Niemiec. Jako reprezentant ludowej SPD, apeluje także do partnerów koalicyjnych o podjęcie problematyki przyszłej egzystencji społeczeństwa multikulturowego, które zbyt długo pozostaje bez odpowiedzi na nurtujące je pytania (Thierse, 2015, s. 13).

Z analizy Federalnego Urzędu Kryminalnego wynika, że ataki na ośrodki dla uchodźców osiagnęły dramatyczny wymiar. Gdy w roku 2012 zaatakowano ośrodki 24 razy, to rok później już 162. Do połowy roku 2015 odnotowano 199 takich napadów. W kategorii wiekowej pośród 341 zatrzymanych 100 podejrzanych było poniżej 25 roku życia, a 19 miało mniej niż 18 lat. W tej grupie zatrzymanych 41 było znanych policji i aresztowanych w przeszłości za czyny motywowane politycznie. Większość stanowili zwykli obywatele (Messer).

Tego zjawiska nie da się już przypisać wyłącznie do wschodnich Niemiec, gdzie skrajna prawica ma swoje bastiony, ale coraz częściej mają one miejsce na zachodzie kraju. W Dortmundzie dziennikarze dostają swoje nekrologii, w Eschenburgu pod Hamburgiem do domu zaadaptowanego na potrzeby azylantów wrzucono płonący kanister,

i Roma. Postawiono 3 pytania badawcze; Jakie grupy społeczne są zagrożone dewaluacją dyskryminacją i przemocą? Jaki jest rozmiar tego procesu i jaki ma przebieg w okresie dekady? Jak można go wytłumaczyć, czerpiąc wiedzę z różnych dyscyplin naukowych? 
pod Norymbergą nieznani sprawcy podpalili świeżo wyremontowane budynki czekające na cudzoziemców, w Saksonii powybijano szyby w redakcjach, a Bodo Ramelow, premier Turyngii, jeździ w opancerzonej limuzynie. Sondaże pokazują, że dwie trzecie Niemców nie ma nic przeciwko uchodźcom z Syrii czy Iraku, ale przeciwnicy są zdesperowani i wyjątkowo skuteczni. Jednoczą się i zakładają stowarzyszenia przeciwko ściaganiu obcych do niemieckich miast (Wieliński, 2015, s. 10).

Od roku 2012 występuje w RFN zjawisko tworzenia się nieformalnych grup bezpaństwowców, którzy nazwali się sami Reichsdeutsche lub Germaniten. Ludzie ci ślą pisma do władz miasta, w których zrzekają się obywatelstwa RFN na rzecz obywatelstwa Wolnego Państwa Prusy. Pod sztandarami pruskiego orła tworzą jednostki policyjne w służbie wolnego państwa pruskiego i nielegalnie pozyskują broń. Administracja niemiecka nie potrafi wymusić uiszczania przez nich obowiązkowych opłat jak: podatek gruntowy, podatki dochodowe, grzywny, mandaty. W korespondencji z urzędami operują prawnymi cytatami i przepisami, powołują się na Niemiecką Rzeszę i jej granice z 1937 r. oraz konstytucję z 30 listopada 1920 r. RFN nie jest dla nich państwem prawa, a firmą, która wymaga jedynie sumiennie wykonywanych obowiązków. Wsparcie uzyskali od znanego muzyka Xaviera Naidoo, który poparł ich na wiecu 3 października 2014 r. w dniu niemieckiej jedności przed budynkiem Reichstagu. Od roku 2014 Urząd Ochrony Konstytucji Nadrenii Północnej Westfalii rejestruje rosnącą liczbę osób identyfikujących się z Prusami, a urząd Brandenburski ostrzega przed nimi w swoich raportach już od roku 2012 (Frigelj, 2015).

\section{Fenomen AfD}

Alternatywa dla Niemiec (AfD) stanowi dla niemieckiej demokracji kuriozum. Dąży ona do współpracy z obozem pro-demokratycznym i równocześnie polityzuje tematy skrajnej prawicy, które są konsekwentnie marginalizowane przez partie demokratyczne. Tworzą ją znamienici, i bez wątpienia demokratycznie myślący politycy, publicyści i ekonomiści, którzy głoszą odejście od euro i stworzenie nowej i mniejszej unii walutowej w europejskich krajach północy. Przyświecające im idee nie są prawicowe ani ekstremistyczne. Jednym z filarów trwałości zdobyczy demokracji niemieckiej i państwa prawa jest zdaniem AfD zasada odpowiedzialności, solidarności i transparentności, w ramach której wolnościowy i demokratyczny porządek prawny zapewnia wolność wypowiedzi i otartą na dyskusję kulturę słowa. W sprzeciwie wobec tendencji zastraszania ludzi o odmiennych poglądach i alienowania ich ze społeczeństwa partia proponuje wprowadzenie w Niemczech i Europie reguł demokracji bezpośredniej, wzorowanej na kulturze szwajcarskiej (Politische). Kierownictwo partii próbuje dystansować się od prawicowego populizmu i ekstremizmu, ale z drugiej strony głosy tych wyborców są jej bardzo potrzebne by dostać się do Bundestagu w 2017 r. (Priester, 2014, s. 34). Obecnie członkowie AfD zasiadają w ławach czterech parlamentów krajowych i partia ma siedmiu przedstawicieli w Parlamencie Europejskim (Europa-Wahlprogramm). Niemieccy badacze sceny politycznej nie dają żadnych nadziei na szybki powrót liberalnej FDP, a Profesor Uwe Jun z Uniwersytetu w Trewirze przewiduje dalsze umacnianie pozycji AfD (Unbequeme). 
Zarówno PEGIDA, jak i AfD dystansują się od brunatnych, którzy biorą aktywny udział w ich demonstracjach. Wiadomo jednak, że działacze AfD należą do aktywistów PEGIDY. Obydwa ruchy mają szansę wzmocnić się dzięki skrywanym w niemieckim społeczeństwie pokładom rasizmu i ksenofobii. Pegida jest domeną wschodnich Landów, nastawionych wyjątkowo antyimigracyjnie, ale sama AfD dominująca w zachodnich landach po kongresie w Essen przekształciła się w ugrupowanie skrajnie prawicowych populistów, które szuka pomysłów na pozbycie się imigrantów i uniemożliwienie im dostępu do niemieckiego rynku pracy. Nowa przewodnicząca 40-letnia Frauke Petry z Saksonii postanowiła uzupełnić program partii skoncentrowany na sprawach UE i strefy euro o klasyczny repertuar prawicowej ekstremy, jak za duża ilość imigrantów, za wiele meczetów, zagrożenie dobrobytu państwa niemieckiego przez bankrutującą Grecję.

Republika Federalna Niemiec „dogania” europejskie tendencje w powstawaniu populistycznych, stabilnych partii prawicowych. Czasy nazizmu utrwalone w kolektywnej pamięci nie zezwalały unii chrześcijańsko-demokratycznej na dopuszczenie jakiejkolwiek demokratycznej partii po prawej stronie sceny politycznej. „Stare” partie prawicowe jak: DVU, Republikaner czy NPD znajdują się na etapie rozkładu najczęściej z powodu różnicy poglądów we własnych szeregach lub kłopotów finansowych (Decker, 2007, s. 251-254, 366-373, 336-343). Samej unii też udawało się kontrolować ich rozwój i w odpowiednim momencie wykorzystać panujące nastroje, by przy pomocy haseł konserwatywno-narodowych trzymać wyborców na dystans od skrajnej prawicy. W efekcie prawicowej ekstremie udawało się uzyskać mandaty w pojedynczych parlamentach krajowych, ale jej przedstawiciele nigdy nie weszli do Bundestagu. Teraz wydaje się, że CDU utraciła swoje konserwatywne skrzydło na zawsze, a wierni do tej pory wyborcy wybrali inną opcję polityczną. Tej straty nie zrekompensowała, jak przed laty, sojusznicza CSU. Ignorowana od początku AfD umacnia się, a przepowiednie o jej rychłym końcu były przedwczesne. Jak trafnie stwierdził „Der Spiegel” w przeciwieństwie do swoich poprzedniczek jest „mniej niechlujna” (Amann, Blome, 2014, s. 22).

\section{Aktywność wyborcza}

Frekwencja wyborcza w Niemczech spada systematycznie. Abnegacja wyborcza jest zjawiskiem nowym w niemieckim społeczeństwie. Symbolizuje demontaż dotychczasowych reguł życia politycznego, które opierały się na zaufaniu obywateli do aparatu władzy i elit politycznych. Politolog z Heidelbergu Wolfgang Merkel ostrzega przed rosnącą ekskluzją ze społeczeństwa coraz większej liczby grup społecznie odrzuconych i rosnącego niezadowolenia $z$ dokonywanych wyborów i polityki w ogóle. Zjawisko to określił mianem ,demokracji dwóch trzecich” lub demokracją połowiczną (halbierte Demokratie) (Brie, 2014, s. 48).

Fundacja Friedricha Eberta zaniepokojona jest wyraźnym wzrostem liczby osób niegłosujących na przestrzeni ostatnich trzech dekad na wszystkich czterech poziomach biernego prawa wyborczego (wybory komunalne, wybory do parlamentów krajowych, wybory do Parlamentu Federalnego, wybory do Europarlamentu). Nawet pojedyncze przypadki stabilności frekwencji nie zmieniają ogólnego trendu wzrostu niechętnych do oddania głosu. 
Niezależny Instytut Badania Opinii Publicznej Forsa przeprowadził na zlecenie fundacji badania na 3500 grupie niegłosujących w okresie ostatnich pięciu wyborów do Parlamentu Federalnego. Opublikowane w 2013 roku wyniki nie potwierdziły braku zainteresowania polityką w ogóle - przeciwnie. Pośród sondowanych $61 \%$ interesowało się polityka, $77 \%$ traktowało wybory za cenną wartość, a tylko $32 \%$ uważało, że oddanie głosów niczego nie zmieni. Nie każdy niegłosujący dystansuje się od wszystkich wyborów. Tylko $14 \%$ skategoryzowane zostało jako stale nie biorący udziału w wyborach do Bundestagu od $1998 \mathrm{r}$. Tylko połowa ankietowanych 46\% tylko jeden raz nie wzięła udziału w wyborach. Porównanie tych grup wykazało, że powtarzające się niegłosowanie prowadzi do dystansu politycznego wobec reguł demokratycznych. Im ktoś częściej nie głosuje, tym bardziej niezadowolony jest z polityki i bardziej krytyczny wobec zasad demokracji. Wśród trwale niegłosujących ponad przeciętną ilość stanowią przedstawiciele mniej uprzywilejowanych grup społecznych. Wyraźna większość niegłosujących $71 \%$ jako powód braku partycypacji wyborczych podawała niezadowolenie z oferty osobowej i programowej partii. Skomplikowany system wyborczy albo zła pogoda podano w $18 \%$. Studia wykazały, że $81 \%$ oczekuje od polityków zainteresowania sprawami obywateli. Do priorytetów politycznych zaliczyli: właściwy system edukacyjny $83 \%$, dobrze funkcjonujący system ochrony zdrowia, w tym dbałość o osoby w podeszłym wieku $68 \%$, gwarancje miejsc pracy $63 \%$. Istnieje szansa, że lepsza oferta partii politycznych skłoni niegłosujących do powrotu do urn (Was). Obywatele o wysokim wykształceniu, stałych dochodach i powiązaniach zawodowych mają większe możliwości reprezentowania własnych interesów. Ci społecznie zróżnicowani nie dostrzegają swojej reprezentacji politycznej, co prowadzi do niskiej partycypacji wyborczej i poczucia jeszcze większej niesprawiedliwości społecznej. Poczucie wyobcowania prowadzi do radykalizacji postaw i jeszcze większej abstynencji wyborczej (Güllner, 2013, s. 83-84).

Prawo do głosowania, jedno ze zdobyczy demokracji, nie przedstawia już większej wartości. To zjawisko obserwowane jest w całej Europie. W Europie Zachodniej w 1975 roku średni udział w wyborach narodowych wynosił $85 \%$, w roku $201275 \%$. W Europie Środkowej spadek jest jeszcze wyższy, bo z 72\% w roku 1991 do $57 \%$ w 2012 roku (Kocka, Merkel, 2014). Frekwencja w wyborach do Bundestagu w 2013 r. wyniosła $71,5 \%$ i była o 0,7 p.p. wyższa niż w wyborach z 2009 r. Do urn poszło 44309925 osób spośród 61946900 uprawnionych do głosowania (w 2009 r. głosowało 44005575 spośród 62168489 uprawnionych do głosowania), zatem o ponad 304 tysięcy więcej niż cztery lata wcześniej. Niemniej frekwencja jest drugą najgorszą od powstania RFN w 1949 r., ale także od momentu zjednoczenia Niemiec i pierwszych wspólnych wyborów do Bundestagu z 2 grudnia 1990 r. Począwszy od 1990 r. frekwencja wyborcza w wyborach do Bundestagu prezentowała się następująco: 1990 r. - 77,8\%, 1994 - 79,0\% (+1,2 p.p.), w 1998 r. $-82,2 \%$ (+3,2 p.p.), w 2002 r. $-79,1 \%$ (-3,1 p.p.), w 2005 r. $-77,7 \%$ (-1,4 p.p.), w 2009 r. $-70,8 \%$ (-6,9 p.p.), w 2013 r. $-71,5$ (+0,7 p.p.) (Schäfer, 2013, s. 39-46). Uwzględniając podział na stare i nowe kraje federacji nadal widać, że Niemcy z Zachodu częściej biorą udział w wyborach. W tzw. starych krajach głosowało $72,5 \%$ uprawnionych do głosowania, a w nowych (a więc na obszarze byłej NRD) tylko 67,6\% (Kubiak, 2014, s. 26).

Z czynnego prawa wyborczego nie korzystają też młodzi Niemcy, jak pokazuje 16. edycja badań firmy Shell. Branie udziału w wyborach przez osoby w wieku pomię- 
dzy 18 a 30 rokiem życia wykazuje od roku 2002 tendencję spadkową, ale w poszczególnych grupach wiekowych procentowy udział określa się jako constans: 18 do $21 \mathrm{r}$. ż. $-70,2 \%$ (2002 r.), 79,0\% (2005 r.), 63,0\% (2009 r.), 21 do 25 r. ż. 68,1\% (2002 r.), $66,5 \%$ (2005 r.), 59,1\% (2009 r.), 25 do 30 r. ż. 72,1\% (2002 r.), 70,1\% (2005 r.), 61,2\% (2009 r.). Wyraźne wahanie w grupie 21-25-latków motywowane jest, według pedagogów, innym rodzajem aktywności życiowych, jak studiowanie i zakładanie rodziny lub rozczarowaniem z zaangażowania wyborczego (Sander, 2015, s. 67-68).

\section{Podsumowanie}

Prawicowy ekstremizm i prawicowy populizm nie jest tylko domeną RFN. Stygmatyzacja grup narodowych i antyeuropejskie refleksy stają się udziałem wielu europejskich państw. Wybory do Parlamentu Europejskiego w maju 2014 roku ,,przekuły” te nastroje w głosy wyborcze i np. Front National uzyskał $25 \%$ poparcie. W tym samym czasie w super roku 2014 wyborów komunalnych w Niemczech przedstawiciele prawicowego i populistycznego nurtu uzyskali mandaty w parlamentach komunalnych AfD uzyskała w Saksonii - 14 mandatów w Brandenburgii i Turyngii po 11, a w wyborach europejskich 7 i 1 mandat uzyskała NPD. Na te zwycięstwa cieniem kładzie się nieskuteczne działania informacyjne rządu i brak dialogu społecznego. $65 \%$ ankietowanych w sondażu tygodnika „Der Spiegel” jest zdania, że unia chrześcijańska i SPD niewystarczająco troszczą się o obywateli w kreowaniu polityki imigracyjnej i azylowej.

Na przekór dominującej w niemieckim społeczeństwie opinii, że 6,6 mln imigrantów stanowi obciążenie dla systemu świadczeń socjalnych badania zlecone przez fundację Bertelsmanna wykazały, że przeciętny imigrant nieposiadający obywatelstwa wpłacił średnio 3,3 tys. euro więcej do systemu świadczeń socjalnych, niż z niego pobrał. W 2012 roku dało to 22 mld euro zysku dla finansów Niemiec (Niemcy).

W społeczeństwie niemieckim następuje też renesans nastrojów antysemickich. Liczba antysemickich czynów kryminalnych wzrosła w ostatnich latach. W roku 2014 było ich 900 . W większości są to ataki werbalne i obelżywe napisy, ale 23 osoby zostały ranne. Rabin Daniel Alter z Berlina potwierdza zjawisko antysemityzmu w szkołach, a sam przed trzema laty był ofiarą ataku w nobliwej dzielnicy Friedenau, a nie jak można przypuszczać zamieszkałej przez muzułmanów Wedding czy Neuköln. Wielu Żydów nie ma odwagi nosić publicznie kipy ani symboli religijnych w postaci łańcuszka z gwiazdą Dawida (Jendroszczyk, 2015).

Również projekt unijny „trzeszczy w posadach”. Niemcy nie chcą ponosić kosztów integracji i sami rozważają opuszczenie strefy euro. Minister spraw zagranicznych Frank Walter Steinmeier przypominał w 100. rocznicę wybuchu I wojny światowej, że dzięki UE udało się znaleźć drogę pokojowego rozwiązywania problemów wynikających z różnicy interesów. Jednak miliony europejczyków nie doceniają wartości pokoju i bezpieczeństwa w Europie. Są one historyczną legitymizacją, na której opiera się UE, ale nie jest już wartością nadrzędną. Młodzi europejczycy stojący w obliczu bezrobocia, braku perspektyw łatwo ulegają retoryce rewizjonistycznej; odświeżane są nacjonalistyczne stereotypy, uprzedzenia nie tylko wobec imigrantów, ale także samych członków społeczności unijnej w określeniach typu „leniwi Grecy”. 
Duży odsetek obywateli odczuwa lęki egzystencjalne i nie dotyczą one tylko grup społecznego marginesu, ale także klasy średniej. Niemcy czekają trudne debaty związane z kryzysem ekonomicznym i finansowym w kraju i Europie, poszukiwanie koncepcji dla funkcjonowania państwa multikulturowego oraz wypracowanie statusu dla skrajnej prawicy. Jeżeli zwolennicy rozwiązań wolnorynkowych i entuzjaści UE nie utrwalą politycznej przewagi, przewidywalny niemiecki system partyjny może ulec dekonstrukcji i zagrozić stabilności europejskiej.

\section{Bibliografia}

Armann M., Blome N., Müller P. (2014), Apo von rechts, „Der Spiegel” 15.12.2014.

Backes U., Jesse E. (1998), Neue Formen des politischen Extremismus w: Jahrbuch Extremismus \& Demokratie, s. 15.

Baumgärtner M., Diehl J. i in. (2014), Neue deutsche Welle, „Der Spiegel” 15.12.2014.

Brie A. (2014), Zwischen Ideologie und praktischer Politik, „Neue Gesellschaft Frankfurter Hefte”, nr 10.

Bobbio N. (1996), Prawica i lewica, Warszawa.

Bürgermeister tritt wegen NPD-Anfeindungen zurück, 10.03.2015, „Die Welt” http://ww.welt.de/regionales/sachsen-anhalt/article138189980/B, 8.03.2015.

Decker F., Neu V. (2007), Handbuch der deutchen Parteien, Wiesbaden.

Europa-Wahlprogramm, https://www.alternativefuer.de/wp-content/uploads/2014/03/Europaprogramm-der-AfD.pdf, 2.08.2015.

Frigelj K. (2015), Was die Reichsbürger wirklich glauben, 16.05.2015, „Die Welt”

Güllner M. (2013), Nichtwähler in Deutschland, Friedrich-Ebert-Stiftung. Forum, Berlin.

Häusler A. (2009), Antiislamischer Rechtspopulismus in der extremen Rechte - die PRO - Bewegung als neue Kraft?, w: Strategien der extremen Rechte. Hintergründe-Analysen-Antworten, red. S. Braun, A. Geisler, M. Gerster, Wiesbaden.

Heitmeyer W. (2012), Deutsche Zustände, Folge 10, Berlin.

Janicka I. (2013), Fala radykalizmu politycznego w Niemczech, „Przegląd Zachodni”, nr 2.

Janicka I. (2015), Niemiecka edukacja obywatelska w zwalczaniu ekstremizmu prawicowego, w: Edukacja obywatelska dorostych a społeczeństwo obywatelskie, red. D. Gierszewski, H. A. Kretek, Racibórz.

Jendroszczyk P. (2014), Multikulti już się przeżyło, „Rzeczpospolita” 20/21.09.2014.

Kocka J., Merkel W. (2014), Demokratie und Kapitalismus:Eine neue Balance wird gesucht, „Neue Gesellschaft Frankfurter Hefte", nr 7/8.

Kubiak P. (2014), Wybory do Bundestagu z 22 września 2013 r., „Przegląd Zachodni”, nr 1.

Bartsch M., Stark H. (2011), Tödliche Welt, „Der Spiegel” 14.03.2011.

Messer, Hämmer, Schlagringe, „Der Spiegel” 1.08.2015.

Mojsiewicz Cz. (1999), Rola opinii publicznej w polityce, Poznań.

Moroska-Bonkiewicz A. (2013), Niemiecka skrajna prawica na tle europejskim, w: Niemiecka scena polityczna 2009-2013, red. A. Kruk, M. Sus, Wrocław.

Osiński W. (2015), Bawaria nie radzi sobie z uchodźcami, „Przegląd” 20/26.04.2015

Politische Leitlinien der Alternative für Deutschland, https://www.alternativefuer.de/wp-content/uploads/2014/05/Politische-Leitlinien-der-Alternative-f\%C3\%BCr-Deutschland-Mai-2014-Version-f\%C3\%BCr-den-Druck.pdf, 20.05.2014. 
Pomarański M. (2011), Ekstremizm, w: M. Marczewska-Rytko, E. Olszewski, Myśl społeczna i ruchy polityczne współczesnego świata, Warszawa.

Popp M. (2012), Florian, wir kriegen dich, „Der Spiegel” 11.06.2012.

Priester K. (2014), Rechtspopulismus im Aufwind, „Neue Gesellschaft Frankfurter Hefte”, nr 4.

Przybylski H. (1975), Ruchy polityczne. Zagadnienia teoretyczne, w: Metodologiczne i teoretyczne problemy nauk politycznych, red. K. Opałek, Warszawa.

Sander A. (2015), Młodzi Niemcy w społeczeństwie obywatelskim w świetle badań Shell, w: Edukacja obywatelska dorostych a społeczeństwo obywatelskie, red. D. Gierszewski, H. Kretek, Racibórz.

Schäfer A. (2013), Wahlbeteiligung Und Nichtwähler, ,Aus Politik und Zeitgeschichte”, nr 48-49.

Szczepański J. (1970), Elementarne pojęcia socjologii, Warszawa.

Thierse W. (2015), Zwischen Ängsten und Ressentiments, „Neue Gesellschaft Frankfurter Hefte”, nr 3.

Tokarczyk R. (2003), Rozważania nad pojęciem ekstremizmu, Annales Universitatis Mariae CurieSkłodowska, Sectio G, Lublin.

UnbequemeFragen, FES-Info 3/2014.

Was Nichtwähler über Politik denken, FES-Info 2/2013.

Wieliński B. T. (2015), Ogniem w imigranta, „Gazeta Wyborcza” 18/19.04.2015.

\section{Right-wing extremist attitudes in German society}

\section{Summary}

The main topic of this paper is the analysis of right-wing extremist sentiments in German society. Representatives of the middle-class are mostly identified with these political tendencies. The unsuccessful multicultural project in the Federal Republic of Germany, long-lasting economic crisis in Europe, Islamic terrorism and the wave of immigrants have led to the spread of xenophobia and racism. Thus, many new parties and various informal groups are being formed that expect the government to change the asylum policy of the state and which express their need to consolidate national identity.

These social groups demonstrate a critical attitude to the German political system, attracting a certain portion of the protesting electorate. One of the citizens' movements, named Pegida, is demonstrating against not only radical Muslims but Islam as a whole. The organizers and supporters of Pegida publicly distance themselves from right-wing extremists, but use the fears of Islamic terror to spread general negative sentiments towards refugees and foreigners. The research question refers to the prospects of instilling democratic standards in the middle class of German society after the post-unification period. This social class may be the most important factor influencing public opinion. The renaissance of fascist ideology has forced the creation of a new model of communication between social classes. The perception of right-wing ideology is the object of research in the axiological sphere.

Key words: multicultural, anti-Semitism, AfD, right-wing extremism 
